\title{
Identification of the mental workload of pub- lic employees in the administrative sector at a public university
}

\author{
Andressa Aline Sontag a, ${ }^{\text {a, }}$ José Mohamud Vilagrab ; Helenara Salvati Bertolossi Moreira ${ }^{\mathrm{c}}$; Antônio \\ Renato Pereira Moro ; Roberto Moraes Cruz ${ }^{\mathrm{d}}$; Pedro Ferreira Reis ${ }^{\mathrm{e}}$; Isabele Maia Galvão ${ }^{\mathrm{f}}$ \\ ${ }^{a}$ Physical Therapy student from Universidade Estadual do Oeste do Paraná - UNIOESTE \\ ${ }^{b}$ Professor of Universidade Estadual do Oeste do Paraná - UNIOESTE and Faculdade Assis Gurgacz - FAG \\ 'Professor of Universidade Estadual do Oeste do Paraná - UNIOESTE \\ ${ }^{d}$ Professor Doctor of Program of Masters Degree in Engineering of Production - PPGEPof Universidade Fed- \\ eral de Santa Catarina - UFSC \\ ${ }^{e}$ Student of PPGEP/UFSC \\ ${ }^{f}$ Physical Therapy student from Universidade Estadual do Oeste do Paraná - UNIOESTE
}

\begin{abstract}
In the workplace there are risk factors that can overwhelm the health of the worker causing physical and psychological disorders. Among these disorders, is occupational stress. Thus, this research proposes to measure the mental workload of job stress from the identification of demand, control and social support. It is an observational cross-sectional epidemiological character, performed with the Rectory office workers at the State University of West Paraná (Unioeste). Data collection was due to the application of the "Job Stress Scale" (JSS) and in its reduced version adapted to Portuguese. The survey sample consisted of 44 individuals. Statistical analysis was correlated inversely with medium intensity $(r=-0.404)$ between age and social support. For males was found between control and age $(\mathrm{r}=0.603)$. According to the data obtained, we conclude that most workers are exposed to passive work, leading to loss of skills or disinterest in the job. This study highlights the importance of research in the area and the need for new actions that change the conditions of stress at work.
\end{abstract}

Keywords: Stress, Job Stress Scale; Occupational Health; mental load.

\section{Introduction}

From the 90's, with acceleration of the restructuring process, the adoption of new technologies, management methods and poor working relationships, increased the prevalence of occupational diseases. For this environment there are several risk factors that affect worker health, which can be divided into individual factors, biomechanical, organizational, psychosocial and environmental. ${ }^{[14,15]}$
The association of risk factors may not be the primary cause of illness, but favor its development, the burdens imposed by the worker. The workload, ie the number of requirements imposed on the worker, loads can be divided into physical, mental, mechanical and ergonomic, and thus trigger the development of physical and psychological disorders in workers. Among these disorders, stress is. ${ }^{[15,3,13]}$

Stress is considered a major public health problems. The word stress was incorporated into the medical and biological sciences, in the $30 \mathrm{~s}$, the physician

*Corresponding author: andressaaline@hotmail.com. Address: Peace River, number: 492, apartment: 3. Phone (45) 9904-9862. 
Hans Selye. Thus, it can be defined as a set of reactions that develops when the body is subjected to a situation that requires effort to adapt. ${ }^{[10,9,6,17]}$

Borges, Luiz e Domingos ${ }^{[4]}$ report that stress can be divided into four phases: alarm, resistance, exhaustion and near-exhaustion. Para Borges, Luiz e Domingos $^{[4]}$ e Baú ${ }^{[3]}$ phases are triggered by internal or external stressors, external occur in the environment, and internal, by the way the individual responds to situations. The answer can be positive (excitement) or negative (distress), which sets it apart is the intensity, frequency, duration of exposure and lack of control in stressful situation. ${ }^{[5,6,14,16]}$

Vulnerability to stressors depends on the perception of each individual and, by extension, the personal characteristics. The lack of autonomy, physical inactivity, obesity and high physical load contribute to the illness of the worker. ${ }^{[7,5,20,11,14,16]}$

Despite the high incidence of psychiatric disorders related to work are often irrelevant for a clinical evaluation. ${ }^{[5]}$

Several studies describe the complexity of the issue and the need for further studies on the etiology of the problem. Therefore, this research proposes to measure the mental workload of job stress from the identification of demand, control and social support.

\section{Methodology}

\subsection{Procedures}

The present study is an observational crosssectional epidemiological character, held the Rectory of the Unioeste, Campus of Cascavel. The same was approved by the Ethics in Research Involving Human Subjects of the Union (case number: 814/2010).

Inclusion criteria incorporate the workers who work in the selected sectors that are most of the record using the computer and agreed to answer the questionnaire without independence of gender and no age limit. The non-inclusion include those who refused to participate and / or that were not part of the sector specifically. And workers who were excluded did not answer the questionnaire correctly.

The questionnaire took place in December 2010, with the approach of workers in their jobs in the early hours by a single examiner. Data were collected after agreeing to voluntary participation in research by signing an informed consent (IC).

For the correct completion of the JSS, the workers received information on the three dimensions (demand, control and social support) for the instrument, but also what is the purpose of the study and the importance of workers participate. Any questions of workers to fill out the questionnaire have been addressed by the researcher.

After collecting the data, they were tabulated and then carried out a simple descriptive analysis to characterize the sample correlation and nonparametric Spearman Bioestat 5.0 in the program.

\subsection{Instrument}

The JSS was developed in Sweden by Töres Theorell in 1988. Social support was added to the model by Johnson in $1988 .^{[8,18,1]}$

The JSS was used in its reduced version and adapted to Portuguese, which contained 17 questions (A through Q): 5 to assess the demand, 6 to evaluate the control and 6 for social support. The answers are presented in Likert scale (1-4). ${ }^{[1]}$

The score of demand, control and social support is obtained through the sum of questions in each dimension. And so, according to Karasek e Theorell ${ }^{[8]}$, quadrants for defining the exposure to work stress, the cutoff points for each dimension are determined by the median found for each one.

The demands refer to psychological demands faced by the worker during the execution of their tasks involve time pressure, concentration level and stop tasks. The control includes aspects relating to the use of skills and decision-making authority. A little control is seen as an environmental restrictions on the responsiveness of the individual, indicating little autonomy in decision-making, and little development of skills. Social support identifies levels of social interaction, existing work, both with colleagues and bosses, so the greater the support, the greater the protection factor against the stress. ${ }^{[8,19,18,6]}$

To that end, after the definition of average scores, four quadrants can be formed, with them, work with high demand (more demand and less control), passive jobs (lower demand and less control), active jobs (demand and higher greater control) and work with less strain (lower demand and greater control). The first being the most harmful, the passive work the second most harmful, active work is the third least harmful and the best situation is the last state that sets up a highly desirable, ideal. ${ }^{[8,6]}$ 


\section{Results and Discussion}

The survey sample consisted of 44 individuals, 30 women and 14 men, with ages ranging from 18 to 53 years, mean $34.34( \pm 10.744)$ years.

From the data obtained through the application of the Job Stress Scale, measured after the demand, control and social support, some found their respective medians, 14, 17 and 22. Were determined four quarters, accounted for $36 \%$ passive work (combines lower demand and less control) 23\% representing high labor requirement (more demand and less control) accounted for 23\% active work (higher demand and greater control) accounted for $18 \%$ low work requirement (less demand and more control). As for social support, which indicates the level of social interaction between workers and bosses, $68 \%$ of individuals characterized less social support, and thus a greater chance of becoming ill.

Statistical analysis was correlated inversely with medium intensity $(r=-0.404)$ between age and social support. For males was found between control and age $(\mathrm{r}=0.603)$ and for females, there was low correlation $(\mathrm{r}=0.269)$.

The results of the instrument in this study corroborate the research of Alves et al. ${ }^{[2]}$ and Macedo et al. $^{[12]}$. At first, the sample consisted of 1,716 women, where $28.3 \%$ of them were also exposed to passive work. And second, which was held in the University of Rio de Janeiro with technical and administrative workers, the sample consisted of 2,343 individuals and among these, $35.4 \%$ were in a passive work. This demonstrates that these studies also obtained as a result a large number of workers who experience work situations passive. Thus, it is recognized that imbalances in the levels of work demands and control produce an increased release of stress hormones. $^{[4]}$

\section{Conclusion}

According to the data obtained, it is concluded that $36 \%$ of workers reported being exposed to passive work, which favors a decline in overall activity of the individual and a reduction in their ability to solve problems, lead to loss of skills and disinterest.

This study highlights the importance of research in the area and the need for new actions that change the conditions of stress at work.

\section{References}

[1] M.G.M. Alves, D. Chor, E. Faerstein, C.S.L. Lopes and G.L. Werneck, Versão resumida da "job stress scale": adaptação para o português, Rev Saúde Pública., 38(2),164-171, 2004.

[2] M.G.M. Alves, D. Chor, E. Faerstein, C.S. Lopes, Estresse no trabalho e hipertensão arterial em mulheres no Estudo PróSaúde, Rev Saúde Publ., 43(5), 93-96, 2009.

[3] L.M.S. Baú, Fisioterapia do Trabalho, Curitiba: Clãdosilva, 2002.

[4] C.S. Borges, A.M.A.G. Luiz and N.A.M. Domingos, Intervenção cognitivo-comportamental em estresse e dor crônica. Arq Ciênc Saúde, 16(4), 181-186, 2009.

[5] J.D. Fernandes, C.M.M. Melo, M.C.C.M Gusmão, J. Fernander, A. Guimarães. Saúde mental e trabalho: Significados e limites de modelos teóricos, Rev Latino-am Enfermagem, 14(5), 803$811,2006$.

[6] A.C.L. França and A.L. Rodrigues, Stress e Trabalho - Uma abordagem Psicossomática, $4^{\mathrm{a}}$ ed., São Paulo, Atlas, 2005.

[7] I. Iida. Ergonomia: projeto e produção, São Paulo: Edgard, Blücher Ltda, 1998.

[8] R. Karasek and T. Theorell. Healthy Work: Stress, Productivity and the Reconstruction of Working Life, New York: Basic Books, 1990.

[9] M.E.N Lipp. O stress no Brasil: pesquisas avançadas, Campinas: Papirus, 2004

[10] M.E.N Lipp and L.E.N Malagris. O stress no Brasil de hoje. In: M.N. Lipp (Org.), O stress no Brasil: pesquisas avançadas, Campinas: Papirus, 2004.

[11] M.E.N, Lipp. Pesquisas Sobre o Stress no Brasil, São Paulo: Papirus, 1996.

[12] L.E.T. Macedo, D. Chor, V. Andreozzi, E. Faerstein, G.L. Werneck and C.S Lopes, Estresse no trabalho e interrupção de atividades habituais, por problemas de saúde, no Estudo Pró-Saúde. Rev Cadernos de Saúde Pública, 23(10), $2327-$ 2336, 2007.

[13] T.S.B.S. Magnago, M.T.L. Lisboa, R.H. Griep, Trabalho da enfermagem e distúrbio musculoesquelético: revisão das pesquisas sobre o tema, Rev de Enferm, 12(1),560-565, 2009.

[14] Ministério da Saúde (Brasil), Organização Pan-Americana da Saúde, Doenças relacionadas ao Trabalho, Manual de procedimentos para os serviços de Saúde, Brasília, Ministério da Saúde, 2001.

[15] C.A.P. Ragasson. Qualidade no Trabalho: Estudo das Condições de Trabalho, Cascavel: Coluna do saber; 2004.

[16] R.P. Rio and L. Pires, Ergonomia: fundamentos da prática ergonômica, $3^{\text {a }}$ ed. São Paulo: São Paulo, 2001.

[17] H. Selye, Stress - a tensão da vida, São Paulo: Ibrasa, 1959.

[18] T. Theorell, L. Alfredson, P. Westerholm and B. Falck Coping with unfair treatment at work - what is the relationship between coping and hypertension in middle-aged men and women?. Psychother Psychosom, 69(2), 86-94, 2000.

[19] T. Theorell, The demand-control-support model for studying health in relation to the work environment: an interactive model. In: K. Orth-Gómer and N. Schneiderman. Behavioral medicine approaches to cardiovascular disease. Mahwah: Lawrence Erlbaum Associates, 1996.

[20] T.I.J. Van Den Berg, L.A.M Elders, B.C.H Zwart and A. Burdorf, The effects of work - related and individual factors on the Work Ability Index: a systematic review, Occup Environ Med., 66(4):211-220, 2009. 